\title{
Serum response to supplemental macular carotenoids in subjects with and without age-related macular degeneration
}

\author{
Katherine A. Meagher ${ }^{1 *}$, David I. Thurnham ${ }^{2}$, Stephen Beatty ${ }^{1,3}$, Alan N. Howard ${ }^{4,5}$, Eithne Connolly ${ }^{1}$, \\ Wayne Cummins ${ }^{6}$ and John M. Nolan ${ }^{1,3}$ \\ ${ }^{1}$ Macular Pigment Research Group, Department of Chemical and Life Sciences, Waterford Institute of Technology, Waterford, \\ Republic of Ireland \\ ${ }^{2}$ Northern Ireland, Centre for Food and Health (NICHE), University of Ulster, Coleraine, UK \\ ${ }^{3}$ Institute of Vision Research, Whitfield Clinic, Waterford, Republic of Ireland \\ ${ }^{4}$ Howard Foundation, Cambridge, UK \\ ${ }^{5}$ Downing College, University of Cambridge, Cambridge, UK \\ ${ }^{6}$ Department of Chemical and Life Sciences, Pharmaceutical and Molecular Biotechnology Research Centre, Waterford \\ Institute of Technology, Waterford, Republic of Ireland \\ (Submitted 14 June 2012 - Final revision received 20 September 2012 - Accepted 20 September 2012 - First published online 5 December 2012)
}

\begin{abstract}
Macular pigment (MP) is composed of lutein (L), zeaxanthin (Z) and meso-zeaxanthin (MZ). The present study reports on serum response to three different MP supplements in normal subjects ( $n$ 27) and in subjects with age-related macular degeneration (AMD) ( $n$ 27). Subjects were randomly assigned to: Group 1 (20 mg L and $2 \mathrm{mg} \mathrm{Z),} \mathrm{Group} 2$ (10 mg L, $2 \mathrm{mg} \mathrm{Z} \mathrm{and} 10 \mathrm{mg}$ MZ) or Group 3 (3 mg L, $2 \mathrm{mg}$ Z and 17 mg MZ). Serum carotenoids were quantified at baseline, and at 4 and 8 weeks using HPLC. Response data for normal and AMD subjects were comparable and therefore combined for analysis. We report response as the average of the 4 - and 8 -week concentrations (saturation plateau). Serum L increased significantly in Group $1(0.036 \mu \mathrm{mol} / \mathrm{l}$ per $\mathrm{mg}(269 \%) ; P<0.001)$ and Group $2(0.079 \mu \mathrm{mol} / 1$ per mg $(340 \%) ; P<0.001)$, with no significant change in Group $3(0.006 \mu \mathrm{mol} / \mathrm{l}$ per $\mathrm{mg}(7 \%) ; P=0 \cdot 466)$. Serum Z increased significantly in Group $1(0.037 \mu \mathrm{mol} / 1 \mathrm{per} \mathrm{mg}(69 \%) ; P=0.001)$ and Group $2(0.015 \mu \mathrm{mol} / 1$ per $\mathrm{mg}(75 \%) ; P<0 \cdot 001)$, with no significant change in Group $3(-0 \cdot 0002 \mu \mathrm{mol} / 1$ per $\mathrm{mg}(-6 \%) ; P=0 \cdot 384)$. Serum MZ increased significantly in Group $1(0.0094 \mu \mathrm{mol} / 1$ (absolute value); $P=0.015)$, Group $2(0 \cdot 005 \mu \mathrm{mol} / 1 \mathrm{per} \mathrm{mg} ; P<0 \cdot 001)$ and Group $3(0.004 \mu \mathrm{mol} / 1$ per $\mathrm{mg} ; P<0.001)$. The formulation containing all three macular carotenoids (Group 2 supplement) was the most efficacious in terms of achieving the highest combined concentration of the three MP constituent carotenoids in serum, thereby potentially optimising the bioavailability of these compounds for capture by the target tissue (retina).
\end{abstract}

Key words: Age-related macular degeneration: Macular carotenoids: Lutein: Zeaxanthin: meso-Zeaxanthin: HPLC separation

Carotenoids are a class of $>700$ tetraterpenoid compounds found in nature. These plant pigments contribute to a plethora of biological functions, due to their unique chemical features $^{(1)}$, where they play important roles in both plants (e.g. the regulation of light in oxygenic photosynthesis ${ }^{(2)}$ ) and animals (e.g. precursors in the formation of vitamin $\mathrm{A}^{(3)}$ ).

Carotenoids contain a conjugated system of double bonds, known as a polyene backbone, which is capped with two end groups. The backbone is responsible for their respective photochemical properties (short-wavelength light absorption) and chemical reactivity (antioxidant capacity), whereas the carotenoids are identified and defined primarily by their respective end groups. One or both end groups can undergo cyclisation as well as substitution with oxygen-containing groups (i.e. keto, hydroxy or epoxy groups), which is why there is such a large variety of carotenoids in nature. Oxygen-containing carotenoids are referred to as xanthophylls (e.g. lutein (L), zeaxanthin (Z) and meso-zeaxanthin (MZ)), while the true hydrocarbon carotenoids are referred to as carotenes (e.g. $\alpha$ - and $\beta$-carotene) (Fig. 1).

$\mathrm{L}, \mathrm{Z}$ and $\mathrm{MZ}$ are the predominant xanthophyll carotenoids found in the macula ${ }^{(4)}$, the central part of the retina responsible for fine detail vision ${ }^{(5)}$. The macula accumulates these yellow carotenoids and excludes all the other thirty or so circulating carotenoids ${ }^{(6)}$, and are collectively known as macular pigments (MP) in this specialised tissue ${ }^{(7)}$.

Abbreviations: AMD, age-related macular degeneration; IS, internal standard; L, lutein; MP, macular pigment; MZ, meso-zeaxanthin; Z, zeaxanthin.

*Corresponding author: K. A. Meagher, email kmeagher@wit.ie 

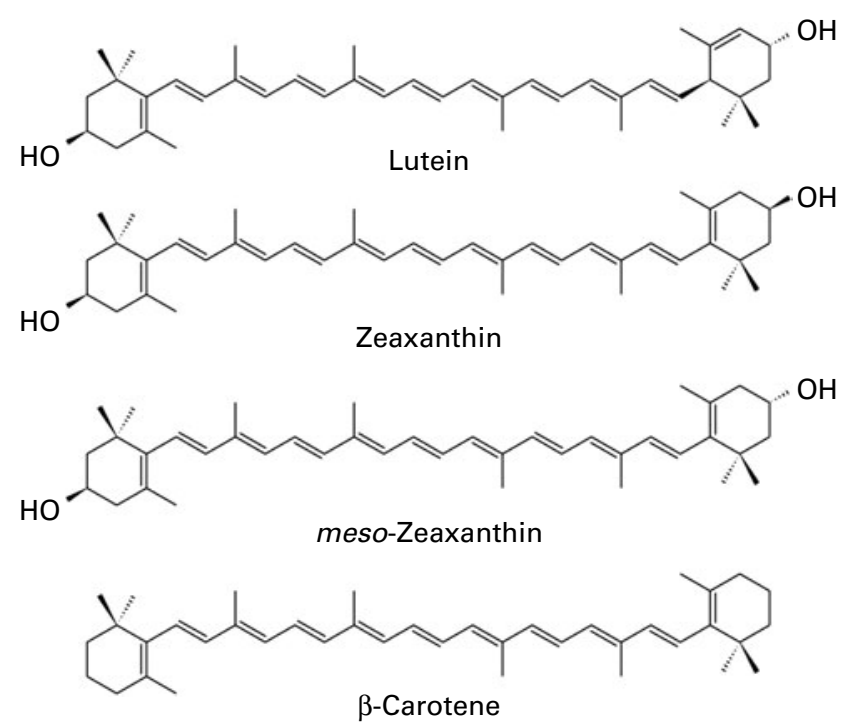

Fig. 1. Chemical structures of the three macular carotenoids lutein, zeaxanthin and meso-zeaxanthin and $\beta$-carotene.

There is a consensus that the macular carotenoids play an important role in protecting the macula from the damaging effects of reactive oxygen species ${ }^{(8)}$. Reactive oxygen species, which can exist as either free radicals or non-radical subgroups, are produced as a result of oxygen metabolism, and their generation is increased when the tissue is exposed to short-wavelength (blue) light and to other environmental (pollution) and lifestyle (smoking) factors ${ }^{(9)}$. Interestingly, the polyene chains of $\mathrm{L}, \mathrm{Z}$ and $\mathrm{MZ}$ have the ability to quench reactive oxygen species ${ }^{(10,11)}$ and absorb shortwavelength (blue) light ${ }^{(1,10,12)}$. Of interest, a study by Li et al. reported that a mixture of $\mathrm{L}, \mathrm{Z}$ and $\mathrm{MZ}$ in vitro, in a ratio of $1: 1: 1$ (the ratio of these carotenoids typically seen in normal $\mathrm{MP})^{(13)}$, can quench more singlet oxygen than the individual carotenoids at the same total concentration, and may explain the exquisite biological selectivity and spatial distribution of these pigments within this specialised retinal tissue ${ }^{(14)}$. The aforementioned properties of the macular carotenoids are believed to confer protection against age-related macular degeneration (AMD), the most common cause of blind registration in the developed world ${ }^{(15,16)}$. Also, the optical (shortwavelength filtering) properties of the macular carotenoids suggest that they play a role in visual function, by reducing the effects of chromatic aberration (and therefore improving image quality) and light scatter (and therefore reducing the symptoms of glare) $)^{(17-19)}$.

$\mathrm{L}$ and $\mathrm{Z}$ cannot be synthesised de novo in mammals and must be obtained from the diet. $\mathrm{L}$ and $\mathrm{Z}$ are found in common foodstuffs such as fruits (e.g. kiwi) and vegetables (e.g. spinach and maize) ${ }^{(20)}$, whereas MZ has not been identified in these foods, although it is important to point out that there has been no published study on MZ concentrations in foods of a typical diet (including fruits and vegetables) as yet. However, Maoka et al. ${ }^{(21)}$ have shown MZ to be present in some unusual foods, such as fish skin and turtle fat. Interestingly, MZ accounts for one-third of MP at the macula, and simian experiments suggest that it is produced by isomerisation of $\mathrm{L}^{(22)}$.

Many studies have reported serum responses to supplemental $\mathrm{L}$ and $\mathrm{Z}$, but only three trials have reported on responses to supplemental $M Z^{(23-25)}$, as this carotenoid was only identified as being present at the macula in $1993^{(4)}$. However, a recent clinical trial by Connolly et $a l^{(26)}$ reported a rapid serum and MP response to a supplement containing all three macular carotenoids and, importantly, none of these trials reported any adverse effects associated with consumption of the macular carotenoids.

The present study was designed to investigate serum carotenoid responses to supplements containing at least two of the three macular carotenoids (i.e. a macular carotenoid supplement comparison study) in subjects with and without AMD.

\section{Methods}

\section{Subjects}

This was a randomised and double-blind study. All subjects signed an informed consent document and the experimental measures conformed to the Declaration of Helsinki. The study was reviewed and approved by the Research Ethics Committees, South East Region, Waterford Regional Hospital, and the Ethics Committee of the Waterford Institute of Technology, Waterford, Ireland.

We were interested in studying two different subject populations, those with and without AMD. These two populations were recruited under the following criteria. Normal subjects were those with no ocular pathology and in good health. Subjects suffering from AMD were defined as those with signs of early AMD, exhibiting drusen and pigmentary changes. The AMD subjects were identified at a pre-project enrolment and screening visit, conducted by an ophthalmologist with a special interest in retinal disease and experienced in the classification of AMD for research purposes (S. B. ${ }^{(27)}$. Exclusion criteria comprised past or present use of supplemental macular carotenoids and/or pregnancy. Subject BMI was calculated $\left(\mathrm{kg} / \mathrm{m}^{2}\right)$. Height $(\mathrm{m})$ was measured using a Leichester Height Measure and weight $(\mathrm{kg})$ was measured using SECA weighing scales (SECA). Smoking status was identified as one of three positions: current smoker, ex-smoker and never smoker. A subject's weekly intake of carotenoid-rich foods (eggs, broccoli, maize and dark leafy vegetables) were inputted into the 'L/Z screener' to give a carotenoid diet 'score'. Values were weighted for frequency of intake of the food and for the bioavailability of $\mathrm{L}$ and $\mathrm{Z}$ within these foods, and a ranking score reflecting the relative intakes was generated. The range of scores from the $\mathrm{L} / \mathrm{Z}$ screener is 0 to 75 . After adding foods with known concentrations of $\mathrm{L}$ and $\mathrm{Z}$ into the screener, the following estimates were made. Low dietary carotenoid intake score is from 0 to 15 (i.e. $\leq 2 \mathrm{mg} / \mathrm{d}$ ); medium dietary carotenoid intake score is from 16 to 30 (i.e. between $>2$ and $13 \mathrm{mg} / \mathrm{d}$ ); and high dietary carotenoid intake score is from 31 to 75 (i.e. $>13 \mathrm{mg} / \mathrm{d}$ ).

Originally, seventy-two subjects were enrolled into the study. However, as the use of supplemental macular 
carotenoids was an exclusion criterion, and following analysis of baseline serum data (performed only after final study visit), we noted that eight subjects had substantial amounts of MZ in their serum. Given that these subjects suffered from AMD (and were based in the Republic of Ireland, where a supplement containing MZ is widely available for patients with AMD) ${ }^{(28)}$, we suspected that they had in fact been supplementing with the macular carotenoids, but had failed to disclose this fact at enrolment.

This was subsequently confirmed by a phone call to each of these volunteers, and data relating to these subjects were excluded from all analyses. Of the remaining sixty-four subjects, ten (one AMD, nine normal) did not attend all three study visits, and were therefore also excluded from the analysis, thus leaving twenty-one, twenty and thirteen subjects in the carotenoid intervention Groups 1, 2 and 3, respectively (see later).

Of these fifty-four subjects, twenty-seven had no ocular pathology (normal subjects) and twenty-seven had previously been diagnosed with AMD (AMD subjects). The fifty-four subjects were split into three different carotenoid intervention groups as follows: Group 1: ( $n$ 21; eleven normal, ten AMD) $20 \mathrm{mg}$ of L and $2 \mathrm{mg}$ of Z ('Ultra Lutein ${ }^{\mathrm{TM}}$, provided by Nature's Plus, Natural Organics, Inc.); Group 2: ( $n$ 20; ten normal, ten AMD) $10 \mathrm{mg} \mathrm{L}, 2 \mathrm{mg} \mathrm{Z}$ and $10 \mathrm{mg}$ MZ (Macushield $^{\mathrm{TM}}$, provided by MacuVision Europe Limited); Group 3: ( $n$ 13; six normal, seven AMD) $3 \mathrm{mg} \mathrm{L}, 2 \mathrm{mg} \mathrm{Z}$ and $17 \mathrm{mg}$ MZ (customised MZ formulation provided by Industrial Organica (not available commercially)). All supplements used in the present study consisted of oil-suspended, unesterified carotenoids provided in gelatine capsules. Each subject was required to consume one capsule daily, with the main meal, for the duration of the 8-week study period, with serum samples taken at baseline, and at 4 and 8 weeks. Significant efforts were made to ensure compliance to the study intervention. Compliance was monitored closely at the biweekly study visits. In addition, subjects were requested to return their supplement packs at their exit visit, and compliance was checked by tablet counting at this visit.

\section{Standards and solvents}

DSM Nutritional Products supplied the $\mathrm{L}$ and $\mathrm{Z}$ reference standards. The MZ standard was supplied by Industrial Organica as a soyabean oil oleoresin. The internal standard (IS) $\alpha$-tocopheryl acetate and all solvents (HPLC grade) used for extraction and HPLC analysis were supplied by Sigma-Aldrich.

\section{Serum carotenoid extraction}

Non-fasting blood samples were collected in $9 \mathrm{ml}$ vacuette tubes containing a 'Z Serum Sep Clot Activator', usually in the morning when subjects arrived at the clinic. The blood samples were allowed to clot at room temperature for approximately $1 \mathrm{~h}$ and then centrifuged at $725 \mathrm{~g}$ for $15 \mathrm{~min}$ in a Gruppe GC 12 centrifuge (Desaga Sarstedt) to separate the serum from the whole blood. The resulting serum samples were stored at $-70^{\circ} \mathrm{C}$ until the time of extraction (maximum 12 months).
Serum $(0.4 \mathrm{ml})$ was micropipetted into clear $1.5 \mathrm{ml}$ Eppendorf tubes labelled according to subject and visit number. IS $(0.2 \mathrm{ml}), \alpha$-tocopheryl acetate $(250 \mathrm{mg} / 1$ ethanol) and $0.3 \mathrm{ml}$ of butylated hydroxyltoluene $(250 \mathrm{mg} / \mathrm{l}$ ethanol $)$ were added and extracted into $0.5 \mathrm{ml}$ of heptane using a Vortex Genie-2 (Scientific Industries) at the highest setting for $2 \mathrm{~min}$, followed by centrifugation with a AccuSpin Micro 17 (Fisher Scientific Ireland) for $5 \mathrm{~min}$ at $400 \mathrm{~g}$.

An aliquot of the upper heptane layer $(0.4 \mathrm{ml})$ was removed to a light-resistant Eppendorf tube, and the heptane extraction was repeated once more, adding a further $0.5 \mathrm{ml}$ of heptane to the original residue. The combined extracts were dried under $\mathrm{N}_{2}$ and stored at $-70^{\circ} \mathrm{C}$ until analysis.

\section{HPLC analysis of serum L and total zeaxanthin (total Z)} (Assay 1)

The HPLC system used for the study was an Agilent 1200 Series (Agilent Technologies Limited) consisting of a quaternary pump, autosampler, thermostat column compartment and a photodiode array detector monitoring a wavelength of $450 \mathrm{~nm}$ for serum carotenoids and $292 \mathrm{~nm}$ for the IS. Sample analysis was carried out in order of subject number and time of visitation. In other words, subjects were batch assessed.

The dried samples were reconstituted in $0.2 \mathrm{ml}$ of the isocratic mobile phase, vortexed at the lowest setting for $1 \mathrm{~min}$ and pipetted into $2.5 \mathrm{ml}$ vials containing $0.35 \mathrm{ml}$ glass inserts (Agilent Technologies Limited). The sample $(0.1 \mathrm{ml})$ was injected via autosampler onto a Phenomenex Ultracarb ODS $3 \mu^{(20)}$ C18 column, $250 \times 4.6 \mathrm{~mm}$ (part number: 00G-025-E0) with a guard column (Phenomenex) and a $0.5 \mu \mathrm{m}$ in-line filter (Upchurch; Sigma-Aldrich). The column was shown to separate the carotenoids of interest in previous studies ${ }^{(25,29)}$.

The method used a premixed isocratic mobile phase consisting of $85 \%$ acetonitrile, $15 \%$ methanol and $0 \cdot 1 \%$ triethylamine, with a stepwise dichloromethane gradient initiated at $15 \mathrm{~min}$ with $10 \%$ dichloromethane over $1 \mathrm{~min}$ and increased to $50 \%$ dichloromethane between 25 and $27 \mathrm{~min}$. The initial flow rate was set at $1 \mathrm{ml} / \mathrm{min}$, and then increased to $2 \mathrm{ml} / \mathrm{min}$ at $15 \mathrm{~min}$ and remained as such for the duration of the dichloromethane gradient. The system resumed initial settings at $34 \mathrm{~min}$. The $\mathrm{L}$ and total $\mathrm{Z}$ (co-eluted $\mathrm{Z}$ and MZ) peaks eluted at approximately 9.9 and $10.5 \mathrm{~min}$, respectively. The IS eluted at $17 \cdot 8 \mathrm{~min}$. The system temperature throughout was maintained at $15^{\circ} \mathrm{C}$. The mixed $\mathrm{Z}$ fraction was collected manually by switching the waste tube to a collection tube a couple of seconds after the peak was observed to start on the monitor. The eluent was dried under $\mathrm{N}_{2}$ and stored for no more than a few days at $-70^{\circ} \mathrm{C}$ for further analysis (Assay 2).

\section{HPLC analysis of serum meso-zeaxanthin (Assay 2)}

The enantiomers $Z$ and $M Z$ present in the total $Z$ peak were separated using a $5 \mu \mathrm{m}$ chiral column (Chiralpak ${ }^{\mathrm{TM}}$ AD column $(250 \times 4.6 \mathrm{~mm})$ ), a guard column (Apex Scientific Limited) and $2 \mu \mathrm{m}$ filter ${ }^{(25)}$. The total $\mathrm{Z}$ fractions were reconstituted by vortex in $0.1 \mathrm{ml}$ of mobile phase ( $n$-hexaneisopropanol, 90:10) and $0.05 \mathrm{ml}$ was then injected using 
normal-phase chromatography and a linear gradient during which the proportion of hexane increased to $95 \%$ over 30 min. MZ, Z and L eluted at approximately 15.8, 18 and $20 \mathrm{~min}$, respectively.

The absolute concentrations of $\mathrm{L}$ and total $\mathrm{Z}$ were calculated directly from the peak areas obtained in Assay 1. The concentrations were quantified using their respective response factors determined by UV-VIS spectroscopy analysis of the individual $\mathrm{L}$ and $\mathrm{Z}$ standards in absolute ethanol. Individual $\mathrm{Z}$ and $\mathrm{MZ}$ concentrations were then quantified from Assay 2, by calculating the percentage proportion of $Z$ and $M Z$ and applying the resulting ratio to the corresponding total $Z$ value (obtained in Assay 1). All chromatographic peaks of interest were manually integrated using the Agilent ChemStation software (Agilent Technologies Ltd).

Absolute carotenoid concentrations were calculated as $\mu \mathrm{mol} / \mathrm{l}$. For purposes of interpretation, we also report the responses of the individual carotenoids as the changes in concentrations per milligram of supplement carotenoid provided. That is, the response was calculated as the average of the 4and 8-week concentrations, or saturation plateau minus baseline values. This allowed for direct comparison between the interventions (Groups 1, 2 and 3), in terms of individual and total serum macular carotenoid responses and controls for the amount of supplement provided.

\section{Capsule carotenoid analysis}

The carotenoid content of the three supplements used in the present study were analysed using the following protocol. A stock solution was made by dissolving the contents of one capsule in $250 \mathrm{ml}$ of acetone. A $0.5 \mathrm{ml}$ aliquot was taken from this stock solution and made up to $25 \mathrm{ml}$ with acetone to give the working solution for the analysis. The working solution was analysed in triplicate.

A measure of $0.4 \mathrm{ml}$ of the working solution was transferred to a glass tube and dried under $\mathrm{N}_{2}$. A measure of $0.1 \mathrm{ml}$ of IS (ethanolic echinenone, $0.4 \mathrm{mg} / 500 \mathrm{ml}$ ) and $0.4 \mathrm{ml}$ methanolic $\mathrm{KOH}(50 \mathrm{~g} / 100 \mathrm{ml})$ was added to the sample. The samples were stoppered and allowed to saponify at $45^{\circ} \mathrm{C}$ for $1 \mathrm{~h}$ in a shaking incubator. The samples were removed and allowed to cool to room temperature. The remaining $\mathrm{KOH}$ was neutralised using $1.5 \mathrm{ml} 1 \mathrm{M}-\mathrm{HCl}$. Butylated hydroxyltoluene in hexane $(1 \mathrm{ml} ; 25 \mathrm{mg} / 100 \mathrm{ml})$ was added to the sample and mixed by vortex for $2 \mathrm{~min}$. The sample layers were allowed to separate under gravity for $5 \mathrm{~min}$ and a $0.5 \mathrm{ml}$ aliquot of the organic layer was removed to an evaporation tube. A measure of $1 \mathrm{ml}$ of hexane was added to the remaining sample, which was vortexed and allowed to separate as earlier. A measure of $1 \mathrm{ml}$ of the hexane layer was removed and combined with the initial extract, which was dried in a solvent concentrator and stored at $-80^{\circ} \mathrm{C}$ until the time of analysis. These samples were analysed using the HPLC method described earlier in order to quantify L, Z and MZ concentrations in each capsule. Of note, tablet carotenoid assessment of the three supplements used in the study was also performed by Industrial Organica (supplier of Intervention 3) and the data are concordant.

\section{Statistical analysis}

Means and standard deviations are presented in the text and tables (SPSS version 17; SPSS, Inc., used for data analysis). SigmaPlot (version 8; SyStat Software) was used for graphical presentations. All data were tested using the non-parametric Kolmogorov-Smirnov test, and they exhibited normal distribution. Between-group differences for numeric data (age, BMI, diet score and serum carotenoid levels) were calculated using ANOVA. Between-group differences for categorical variables (sex, smoking habits, sex and ocular status (normal or AMD)) were calculated using the standard $\chi^{2}$ test. Difference between baseline and saturation point (i.e. average of weeks 4 and 8) was investigated for $\mathrm{L}, \mathrm{Z}$ and $\mathrm{MZ}$ using paired-sample $t$ tests. Repeated measures analysis was used to test for differences in response of each carotenoid between normal subjects and subjects with AMD, by testing for a time/subject group (i.e. normal subjects $v$. AMD subjects) interaction effect (Greenhouse-Geisser significance values were used and presented in the results section). A $5 \%$ level of significance was implemented throughout the analysis.

\section{Results}

The demographic, lifestyle, ocular disease status (normal or AMD) and baseline serum carotenoid data for all three groups are presented in Table 1. There were no statistically significant differences between groups for baseline parameters, with the exception of significantly higher mean serum Z concentration for subjects in Group 3.

There was no significant difference between normal subjects and AMD subjects with respect to any of the known possible confounders for carotenoids (e.g. BMI, sex and smoking habits), with the exception of a significant difference between these populations for age, which was principally due to the older AMD subjects in Group $1(P=0 \cdot 024)$. Also, there were no significant differences between normal subjects and AMD subjects in terms of baseline serum concentrations of the macular carotenoids or in terms of the responses to any of the three carotenoids (with one exception, Group 3 response to MZ, discussed later). Therefore, data for normal and AMD subjects were combined for the main analyses reported here (Table 2). Furthermore, there were no differences in the serum carotenoid responses between weeks 4 and 8 , and these data were therefore averaged to provide data on the serum response at saturation point.

\section{Supplement assessment}

Table 3 presents the findings of the capsule analysis for each intervention used in the trial. The chromatograms in Fig. 2 show the presence of $\mathrm{MZ}$ in the UltraLutein ${ }^{\mathrm{TM}}$ (intervention Group 1) supplement.

\section{Serum lutein response}

There was no significant difference with respect to serum L response between normal subjects and subjects with AMD 
Table 1. Demographic, lifestyle, ocular status (normal or early age-related macular degeneration (AMD)) and baseline serum carotenoid data for the three intervention groups

(Mean values and standard deviations or number of subjects)

\begin{tabular}{|c|c|c|c|c|c|c|c|c|c|}
\hline \multirow[b]{2}{*}{ Characteristics } & \multicolumn{2}{|c|}{ All } & \multicolumn{2}{|c|}{$\begin{array}{c}\text { Group } 1 \\
(n 21)^{*}\end{array}$} & \multicolumn{2}{|c|}{$\begin{array}{c}\text { Group } 2 \\
(n 20) \dagger\end{array}$} & \multicolumn{2}{|c|}{$\begin{array}{c}\text { Group } 3 \\
(n 13) \ddagger\end{array}$} & \multirow[b]{2}{*}{$P \S$} \\
\hline & Mean & SD & Mean & SD & Mean & SD & Mean & SD & \\
\hline Number of subjects $(n)$ & \multicolumn{2}{|c|}{54} & \multicolumn{2}{|c|}{21} & \multicolumn{2}{|c|}{20} & \multicolumn{2}{|c|}{13} & \multirow{3}{*}{$0.940 \|$} \\
\hline Normal & \multicolumn{2}{|c|}{27} & \multicolumn{2}{|c|}{11} & \multicolumn{2}{|c|}{10} & \multirow{2}{*}{\multicolumn{2}{|c|}{$\begin{array}{l}6 \\
7\end{array}$}} & \\
\hline AMD & \multirow{2}{*}{\multicolumn{2}{|c|}{27}} & \multicolumn{2}{|c|}{10} & \multicolumn{2}{|c|}{10} & & & \\
\hline \multicolumn{8}{|l|}{ Age (years) } & & \\
\hline Normal subjects & 60 & 10 & 59 & 11 & 59 & 11 & 63 & 4 & 0.6329 \\
\hline AMD subjects & 66 & 7 & $70^{\star *}$ & 7 & 66 & 5 & 64 & 13 & 0.267 ๆ \\
\hline BMI $\left(\mathrm{kg} / \mathrm{m}^{2}\right)$ & 27 & 3 & 28 & 4 & 26 & 2 & 27 & 3 & 0.190 ฯ \\
\hline Diet score & 22 & 9 & 22 & 8 & 19 & 9 & 26 & 10 & 0.113 \\
\hline \multicolumn{10}{|l|}{$\operatorname{Sex}(n)$} \\
\hline Male & \multicolumn{2}{|c|}{20} & \multicolumn{2}{|c|}{5} & \multicolumn{2}{|c|}{10} & & & \multirow[t]{2}{*}{$0 \cdot 220 \|$} \\
\hline Female & & & & & & & & & \\
\hline \multicolumn{10}{|l|}{ Smoking habits $(n)$} \\
\hline Never smoker & \multicolumn{2}{|c|}{31} & \multicolumn{2}{|c|}{11} & \multicolumn{2}{|c|}{12} & & & \multirow{3}{*}{$0.355 \|$} \\
\hline Ex-smoker & & & & & & & & & \\
\hline Current smoker & \multicolumn{2}{|c|}{6} & \multicolumn{2}{|c|}{2} & \multicolumn{2}{|c|}{4} & \multicolumn{2}{|c|}{0} & \\
\hline \multicolumn{10}{|l|}{ Serum carotenoids } \\
\hline $\mathrm{L}(\mu \mathrm{mol} / \mathrm{l})$ & 0.25 & 0.15 & 0.26 & 0.16 & 0.23 & 0.14 & 0.27 & 0.13 & $0.702 \uparrow$ \\
\hline $\mathrm{Z}(\mu \mathrm{mol} / \mathrm{l})$ & 0.05 & 0.03 & 0.05 & 0.03 & 0.04 & 0.03 & 0.07 & 0.03 & $0.0129 \dagger \dagger$ \\
\hline $\mathrm{MZ}(\mu \mathrm{mol} / \mathrm{l})$ & 0 & - & 0 & - & 0 & - & 0 & - & - \\
\hline
\end{tabular}

L, lutein; Z, zeaxanthin; MZ, meso-zeaxanthin

${ }^{*}$ High $\mathrm{L}$ group $(20 \mathrm{mg} \mathrm{L} / \mathrm{d}$ and $2 \mathrm{mg} \mathrm{Z} / \mathrm{d})$.

† Combination group (10 mg L/d, $2 \mathrm{mg} \mathrm{Z} / \mathrm{d}$ and $10 \mathrm{mg} \mathrm{MZ} / \mathrm{d}$ ).

$\ddagger$ High MZ group ( $3 \mathrm{mg} \mathrm{L} / \mathrm{d}, 2 \mathrm{mg} \mathrm{Z/d}$ and $17 \mathrm{mg} \mathrm{MZ/d}$ ).

$\S$ Significance difference between the three intervention groups.

II Significance $(P)$ values calculated using the standard $\chi^{2}$ test.

I) Significance $(P)$ values calculated using ANOVA.

** Significant difference with respect to age between AMD and normal subjects in Group $1(P=0.024)$.

†† Group 3 baseline serum $Z$ was significantly greater than Groups 1 and 2; BMI, sex, smoking habits and diet scores information did not differ between AMD and normal subjects and were therefore reported as combined values.

(Group 1: $P=0.409$; Group 2: $P=0.843$; and Group 3: $P=0.571$ ). Serum L concentrations (for normal and AMD subjects combined) increased significantly in Group 1 $(0.036 \mu \mathrm{mol} / 1$ per $\mathrm{mg}(269 \%)$ increase; $P<0.001)$ and Group $2(0.079 \mu \mathrm{mol} / \mathrm{l}$ per $\mathrm{mg}(340 \%)$ increase; $P<0.001)$, with no significant change seen in Group $3(0.006 \mu \mathrm{mol} / 1$ per $\mathrm{mg}(7 \%)$ increase; $P=0.466)$. Serum L concentrations at the three study visits and the saturation point responses are presented in Tables 2 and 4, respectively.

\section{Serum zeaxanthin response}

There was no significant difference with respect to serum $Z$ response between normal subjects and subjects with AMD (Group 1: $P=0 \cdot 198$; Group 2: $P=0 \cdot 626$; and Group 3: $P=0 \cdot 404$ ). Serum $Z$ concentrations (for normal and AMD subjects combined) increased significantly in Group $1(0.037 \mu \mathrm{mol} / 1$ per $\mathrm{mg}$ (69\%) increase; $P=0.001)$ and Group $2(0.015 \mu \mathrm{mol} / \mathrm{l}$ per $\mathrm{mg}$ (75\%) increase; $P<0 \cdot 001$ ), with no significant change seen in Group $3(-0.0002 \mu \mathrm{mol} / 1$ per $\mathrm{mg}(6 \%)$ decrease; $P=0.384)$. Serum $Z$ concentrations at the three study visits and the saturation point responses are presented in Tables 2 and 4, respectively.

\section{Serum meso-zeaxanthin response}

There was no significant difference with respect to serum MZ response between normal subjects and subjects with AMD for either Group $1(P=0.675)$ or for Group $2(P=0.985)$. However, there was a significant difference for subjects in Group 3, with AMD subjects demonstrating a significantly greater serum MZ response than normal subjects following supplementation with this carotenoid (AMD subjects: 0.094 $\mu \mathrm{mol} / \mathrm{l}$ at saturation point $(0.006 \mu \mathrm{mol} / \mathrm{l}$ per $\mathrm{mg}$ increase); normal subjects: $0.036 \mu \mathrm{mol} / 1$ at saturation point $(0.002 \mu \mathrm{mol} / 1$ per $\mathrm{mg}$ increase); $P=0.014$ ) (Fig. 3).

Although there was no MZ declared in the Group 1 supplement, a small concentration of $\mathrm{MZ}$ appeared to be present in serum at weeks 4 and $8(0.009 \mu \mathrm{mol} / \mathrm{l}$ at week $8 ; P=0 \cdot 015)$. Serum MZ concentrations increased significantly in Group 2 $(0.005 \mu \mathrm{mol} / \mathrm{l}$ per $\mathrm{mg}$ increase; $P<0.001)$ and Group 3 $(0.004 \mu \mathrm{mol} / 1$ per $\mathrm{mg}$ increase; $P<0.001)$. As $\mathrm{MZ}$ was not included as a supplemental carotenoid in Group 1, the MZ response can only be presented as the absolute value of MZ in $\mu \mathrm{mol} / 1$ (Table 2). Serum MZ concentrations at the three study visits and the saturation concentration are presented in Tables 2 and 4, respectively.

\section{Total macular carotenoid serum response}

There was no significant difference with respect to total serum carotenoid response between normal subjects and subjects with AMD (Group 1: $P=0.393$; Group 2: $P=0.842$; and Group 3: $P=0 \cdot 152$ ). Total serum carotenoid concentrations (for normal and AMD subjects combined) increased significantly in Group 1 
Table 2. Concentrations of serum lutein (L), zeaxanthin (Z), meso-zeaxanthin (MZ) and total macular carotenoids for each of the three carotenoid intervention groups investigated*

(Mean values and standard deviations) $\dagger$

\begin{tabular}{|c|c|c|c|c|c|c|c|}
\hline & \multicolumn{2}{|c|}{ Baseline $(\mu \mathrm{mol} / \mathrm{l})$} & \multicolumn{2}{|c|}{$\begin{array}{l}4 \text { weeks } \\
(\mu \mathrm{mol} / \mathrm{l})\end{array}$} & \multicolumn{2}{|c|}{$\begin{array}{l}8 \text { weeks } \\
(\mu \mathrm{mol} / \mathrm{l})\end{array}$} & \multirow[b]{2}{*}{$P \ddagger$} \\
\hline & Mean & SD & Mean & SD & Mean & SD & \\
\hline \multicolumn{8}{|l|}{ L } \\
\hline Group 1§ & 0.264 & 0.162 & 1.085 & 0.766 & 0.866 & 0.617 & 0.000 \\
\hline Group 2\| & 0.233 & 0.141 & 0.954 & 0.480 & 1.095 & 0.628 & 0.000 \\
\hline Group 3ף & 0.273 & 0.134 & 0.290 & 0.092 & 0.292 & $0 \cdot 105$ & 0.501 \\
\hline \multicolumn{8}{|l|}{ Z } \\
\hline Group 1§ & 0.046 & 0.027 & 0.081 & 0.049 & 0.075 & 0.044 & 0.000 \\
\hline Group 2\| & 0.040 & 0.025 & 0.067 & 0.033 & 0.074 & 0.043 & 0.000 \\
\hline Group 39 & $0.071^{\star \star}$ & 0.033 & 0.066 & 0.038 & 0.066 & 0.033 & 0.287 \\
\hline \multicolumn{8}{|l|}{ MZ } \\
\hline Group $1 \S$ & - & - & 0.007 & 0.006 & 0.009 & 0.016 & 0.014 \\
\hline Group 2\| & - & - & 0.046 & 0.032 & 0.063 & 0.049 & 0.000 \\
\hline Group 39 & - & - & 0.061 & 0.044 & 0.073 & 0.056 & 0.000 \\
\hline \multicolumn{8}{|c|}{ Total macular carotenoids $\dagger \dagger$} \\
\hline Group 1§ & 0.310 & $0 \cdot 181$ & $1 \cdot 173$ & 0.816 & 0.951 & 0.651 & 0.000 \\
\hline Group 2\| & 0.273 & 0.160 & 1.068 & 0.535 & 1.233 & 0.714 & 0.000 \\
\hline Group 39 & 0.344 & 0.156 & 0.417 & 0.150 & 0.431 & $0 \cdot 180$ & 0.042 \\
\hline
\end{tabular}

* Repeated measures analysis found no differences in response of each carotenoid between normal subjects and subjects with AMD except in Group 3 (see text).

† Mean values were in response to each carotenoid component for each group.

¥Significance $(P)$ values represent paired-sample $t$ tests significance for the increase between baseline and 8 weeks. There were no differences in carotenoid concentrations between weeks 4 and 8 .

$\S$ Group 1 ( $n$ 21): high L group (20 mg L/d and $2 \mathrm{mg} \mathrm{Z/d).}$

\|Group 2 ( $n$ 20): combination group (10 mg L/d, $2 \mathrm{mg} \mathrm{Z/d} \mathrm{and} 10 \mathrm{mg} \mathrm{MZ} / \mathrm{d}$ ).

ๆ Group 3 ( $n$ 13): high MZ group (3 mg L/d, $2 \mathrm{mg} \mathrm{Z/d} \mathrm{and} 17 \mathrm{mg} \mathrm{MZ} / \mathrm{d})$.

${ }^{\star \star}$ There were no differences in baseline concentrations, except for $Z$, in Group 3 (see Table 1).

t† Mean values were in response to each carotenoid component for all three carotenoids in each supplement.

$(0.036 \mu \mathrm{mol} / 1$ per $\mathrm{mg}(242 \%)$ increase; $P<0.001)$, Group 2 $(0.040 \mu \mathrm{mol} / \mathrm{l}$ per $\mathrm{mg}(321 \%)$ increase; $P<0.001)$ and Group $3(0.004 \mu \mathrm{mol} / 1$ per $\mathrm{mg}(24 \%)$ increase; $P=0 \cdot 030)$. Total serum macular carotenoid response over the three study visits and to saturation point is presented in Tables 2 and 4, respectively.

\section{Discussion}

The present study was conducted to investigate serum responses in normal subjects and in those with early AMD to three different macular carotenoid interventions, and is the first study to do so. We believe detailed investigation into serum macular carotenoid response is required, given that serum is the transporter of these carotenoids to their target tissues, including the retina. Moreover, the question as to whether there are differences in response between normal subjects and subjects with AMD is important, and was uniquely answered in the present study.

To this point, we report that subjects with AMD are comparable with normal subjects in how they respond to macular carotenoid supplements in serum, with the exception of a difference between these subject populations in response to

Table 3. Declared and measured carotenoid content of the three study supplements

\begin{tabular}{|c|c|c|c|c|c|c|c|}
\hline \multirow[b]{2}{*}{ Group } & \multirow[b]{2}{*}{ Supplement } & \multicolumn{3}{|c|}{$\begin{array}{l}\text { Declared carotenoid content } \\
\text { (mg/capsule) }\end{array}$} & \multicolumn{3}{|c|}{$\begin{array}{l}\text { Measured carotenoid content } \\
\text { (mg/capsule) }\end{array}$} \\
\hline & & $\mathrm{L}$ & z & $\mathrm{MZ}$ & L & Z & $M Z$ \\
\hline $1^{*}$ & UltraLutein ${ }^{\mathrm{TM}} \dagger$ & 20 & 0.86 & - & $22 \cdot 23$ & $2 \cdot 21$ & 0.30 \\
\hline $2 \ddagger$ & Macushield ${ }^{\mathrm{TM}} \S$ & 10 & 2 & 10 & $10 \cdot 14$ & 1.94 & $12 \cdot 71$ \\
\hline $3 \|$ & Customised MZq & 3 & 2 & 17 & 3.54 & $2 \cdot 72$ & $19 \cdot 24$ \\
\hline
\end{tabular}

L, lutein; Z, zeaxanthin; MZ, meso-zeaxanthin.

* Group 1 ( $n$ 21; eleven normal and ten age-related macular degeneration (AMD)).

†Provided by Nature's Plus, Natural Organics, Inc., Melville, NY, USA.

$\ddagger$ Group 2 ( $n$ 20; ten normal and ten AMD).

$\S$ Provided by MacuVision Europe Limited, Solihull, UK.

\| Group 3 ( $n$ 13; six normal and seven AMD).

Iी Provided by Industrial Organica, Monterrey, Mexico (not available commercially). 

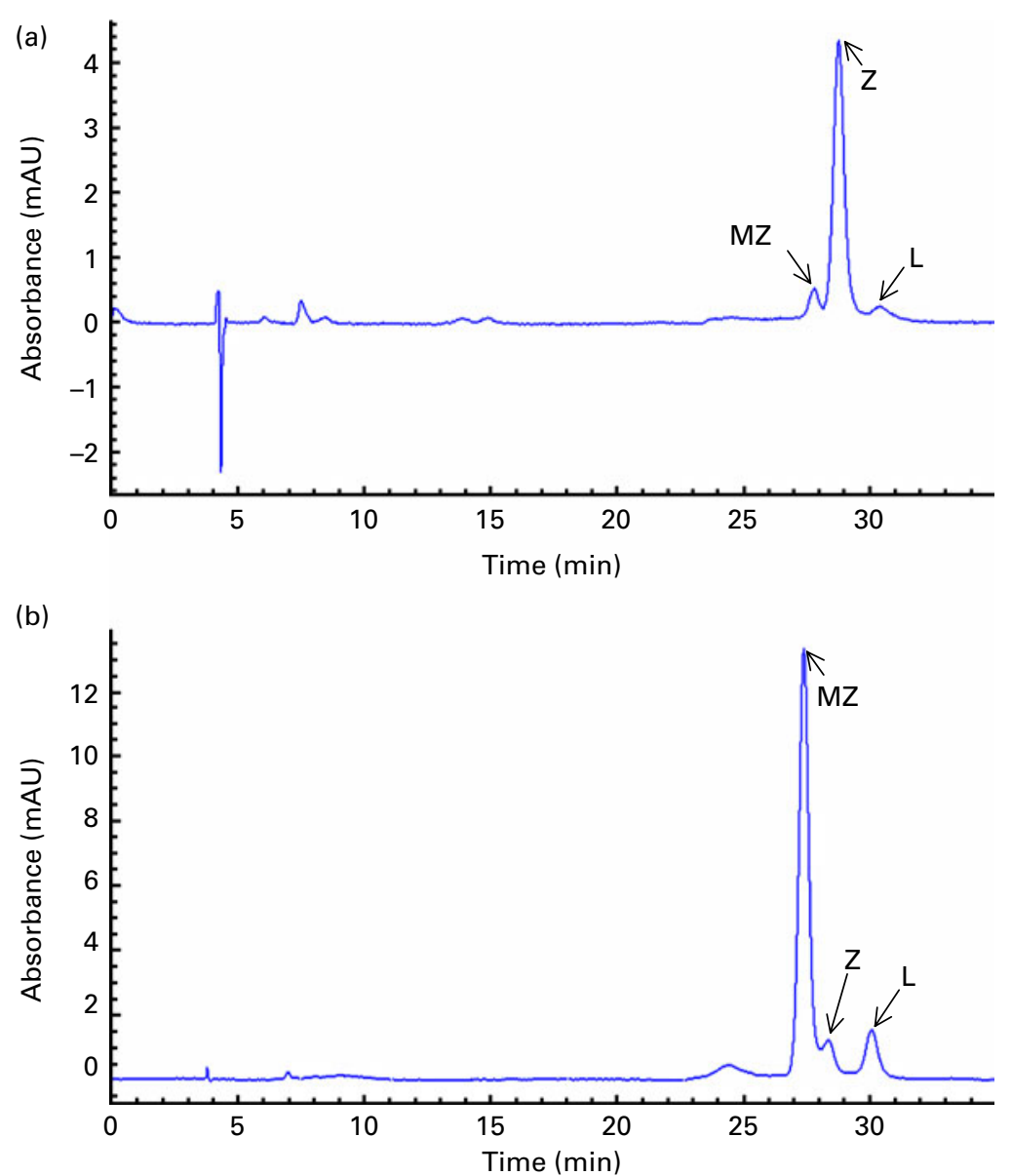

Fig. 2. (a) HPLC analysis of the UltraLutein ${ }^{\mathrm{TM}}$ (intervention used by Group 1) supplement and (b) HPLC analysis of meso-zeaxanthin (MZ) reference standard. L, lutein; Z, zeaxanthin. (A colour version of this figure can be found online at http://www.journals.cambridge.org/bjn).

supplementation with the central macular carotenoid, MZ. Of note, we report no significant difference in serum $\mathrm{L}$ or serum $\mathrm{Z}$ response between these subject populations for any of the interventions tested. However, the Group 3 formulation (i.e. very high $\mathrm{MZ}$ group) yielded significantly different serum MZ responses between the AMD and normal populations, with the MZ response amongst AMD subjects significantly greater than that observed for normal subjects. This seemingly counterintuitive observation is difficult to explain, but may reflect enhanced absorption of this macular carotenoid in subjects who exhibit tissue deficiencies of $\mathrm{MZ}$, reflected in the absence of a typical central peak in MP optical density spatial profile in association with risk factors for $\mathrm{AMD}^{(30)}$. However, the main finding from the present study is that normal and AMD subjects responded comparably to the three different macular carotenoid interventions. This is an important finding, as it confirms that the known lack of MP seen in subjects afflicted with ${ }^{(31)}$, or at high risk of developing ${ }^{(32)}$, AMD is not due to an inability of such subjects to respond to carotenoid consumption, and is therefore due to either a defective capture of circulating carotenoids by, or stabilisation within, the central retina. Our data are consistent with a publication by Wang et $a l .{ }^{(33)}$ who studied subjects with and without AMD following dietary modification (increased consumption of spinach, maize, cabbage, circa $11 \mathrm{mg} / \mathrm{d}$ of $\mathrm{L}$ and $\mathrm{Z}$ (combined), in the highcarotenoid-fed group) and reported no difference between these group in terms of serum concentrations of $\mathrm{L}$ and $\mathrm{Z}$.

Given that, by and large and with the exception of response to supplementation with high-dose $\mathrm{MZ}$, there were no differences between subjects with and without AMD in terms of response to supplementation with MP's constituent carotenoids, we elected to treat our dataset as a single and merged set of data.

We examined the literature to determine the carotenoid responses reported by other researchers, in order to allow comparison with our findings. Examination of these studies has shown that it has been a common practice for other researchers to report carotenoid response in terms of concentrations and/or percentage increases. Presenting the data as percentages and/or concentrations, however, makes it very difficult to interpret the data, as baseline concentrations can vary considerably between subjects. It was for this reason that we constructed and present Table 5 . Table 5 presents data on serum L, Z and MZ responses of these other published studies, but we have converted their data to the unit reported in the present study, which is serum response per mg of supplemental carotenoid (controlling for the amount of carotenoid given and the baseline values). Interestingly, upon 
Table 4. Serum lutein (L), zeaxanthin (Z), meso-zeaxanthin (MZ) and total carotenoid response in $\mu \mathrm{mol} / \mathrm{l}$ per mg of supplemental carotenoid to carotenoid saturation point

(Mean values and standard deviations)

\begin{tabular}{|c|c|c|c|c|c|}
\hline & Mean $(\mu \mathrm{mol} / \mathrm{l}$ per mg) & SD & Significance for group difference ${ }^{*}$ & Increase (\%) & $P \dagger$ \\
\hline \multicolumn{6}{|l|}{ L } \\
\hline Group $1(n 21) \ddagger$ & 0.036 & 0.027 & $(1 v .2)=0.000$ & 269 & 0.000 \\
\hline Group $2(n 20) \S$ & 0.079 & 0.041 & $(1 v .3)=0.038$ & 340 & 0.000 \\
\hline Group $3(n 13) \|$ & 0.006 & 0.029 & $(2 v .3)=0.000$ & 7 & 0.466 \\
\hline \multicolumn{6}{|c|}{ (-7) } \\
\hline Group $1(n 21) \ddagger$ & 0.016 & 0.018 & $(1 v .2)=0.984$ & 69 & 0.001 \\
\hline Group $2(n 20) \S$ & 0.015 & 0.009 & $(1 v .3)=0.001$ & 75 & 0.000 \\
\hline Group $3(n 13) \|$ & -0.002 & 0.008 & $(2 v .3)=0.001$ & -6 & 0.384 \\
\hline \multicolumn{6}{|l|}{$\mathrm{MZ}$} \\
\hline Group $1(n 21) \ddagger$ & $-\eta^{\star *}$ & -9 & $(1 v .2)=0.000^{\star *}$ & - & 0.002 \\
\hline Group $2(n 20) \S$ & 0.005 & 0.003 & $(1 v .3)=0.000^{* *}$ & - & 0.000 \\
\hline Group $3(n 13) \|$ & 0.004 & 0.002 & $(2 v .3)=0.257$ & - & 0.000 \\
\hline \multicolumn{6}{|c|}{ Total macular carotenoid $†$} \\
\hline Group $1(n 21) \ddagger$ & 0.036 & 0.027 & $(1 v .2)=0.831$ & 242 & 0.000 \\
\hline Group $2(n 20) \S$ & 0.040 & 0.021 & $(1 v .3)=0.000$ & 321 & 0.000 \\
\hline Group $3(n 13) \|$ & 0.004 & 0.005 & $(2 v .3)=0.000$ & 24 & 0.030 \\
\hline \multicolumn{6}{|c|}{$\begin{array}{l}\text { * Significance values refer to ANOVA testing with post hoc analysis for significant difference (Tukey honestly significant differences) in serum caro- } \\
\text { tenoid response between intervention groups. }\end{array}$} \\
\hline \multirow{2}{*}{\multicolumn{6}{|c|}{$\begin{array}{l}\text { † Significance }(P) \text { values represent paired-sample } t \text { tests for the increase in serum carotenoids between baseline and the average concentration at } \\
\text { visits } 4 \text { and } 8 \text { weeks. }\end{array}$}} \\
\hline & & & & & \\
\hline \multicolumn{6}{|c|}{ ¥ High L group $(20 \mathrm{mg} \mathrm{L} / \mathrm{d}$ and $2 \mathrm{mg} \mathrm{Z} / \mathrm{d})$. } \\
\hline \multicolumn{6}{|c|}{$\begin{array}{l}\text { § Combination group }(10 \mathrm{mg} \mathrm{L} / \mathrm{d}, 2 \mathrm{mg} \text { Z/d and } 10 \mathrm{mg} \mathrm{MZ} / \mathrm{d}) \\
\| \text { High } \mathrm{MZ} \text { group }(3 \mathrm{mg} \mathrm{L} / \mathrm{d}, 2 \mathrm{mg} \mathrm{Z} / \mathrm{d} \text { and } 17 \mathrm{mg} \mathrm{MZ} / \mathrm{d}) .\end{array}$} \\
\hline \multicolumn{6}{|c|}{$\begin{array}{l}\text { I The intervention taken by Group } 1 \text { did not contain } M Z \text {, therefore an } M Z \text { response per } \mathrm{mg} \text { of supplemental MZ could not be calculated. } \\
{ }^{\star} \text { ANOVA calculated using mean concentrations as } \mu \mathrm{mol} / / \text { for comparisons with Group } 1 \text { results. Total macular carotenoid, combined } \mathrm{L}, \mathrm{Z} \text { and } \mathrm{MZ}\end{array}$} \\
\hline
\end{tabular}

examination of this table with respect to $\mathrm{L}$ response of the other published studies (and excluding our own data), we found that the mean response was 0.066 (SD 0.042) with a range of $0 \cdot 01-0 \cdot 17 \mu \mathrm{mol} / \mathrm{l}$ per $\mathrm{mg}$. Also, for $\mathrm{Z}$ response (and excluding our own data), the mean response was lower at 0.050 (SD 0.035) with a range of $0.004-0.15 \mu \mathrm{mol} / 1$ per $\mathrm{mg}$. Thus, the range of serum macular carotenoid response reported in the literature is very wide. Of note, the responses observed in the present study fall comfortably within the ranges reported in these other studies (see Table 5).

As seen in Table 5, studies investigating serum carotenoid response to $\mathrm{MZ}$ are few, although Connolly et $a l^{(23)}$ and Thurnham et $a l .{ }^{(25)}$ did study and report on $\mathrm{MZ}$ response in normal men and women to a supplement similar in composition to that used in Group 2 here. Although it is known that there is considerable inter-individual variation in terms of MP response to any dietary/supplement intervention ${ }^{(34)}$, there are no published reports of studies designed to investigate serum response to differing macular carotenoid formulations.

\section{Serum lutein response}

$\mathrm{L}$ was present in each of the three carotenoid group interventions. However, Group 1 (the high L group) contained approximately double that of Group 2 and six times that of Group 3. As expected, Groups 1 and 2 demonstrated the greatest serum response to L $(0.036 \mu \mathrm{mol} / \mathrm{l}$ per $\mathrm{mg}(269 \%)$ and $0.079 \mu \mathrm{mol} / 1$ per $\mathrm{mg}(340 \%)$, respectively), with Group 3 demonstrating no response $(0.006 \mu \mathrm{mol} / 1$ per $\mathrm{mg}(6 \%))$.

The Group 1 response is consistent with a previous study by Johnson et al. ${ }^{(35)}$, who used a similar formulation. Of interest, the Group 2 supplement, which contained only half the amount of L compared with that of Group 1, but also contained $10 \mathrm{mg}$ of $\mathrm{MZ}$ and $2 \mathrm{mg}$ of $\mathrm{Z}$, achieved a significantly greater serum $\mathrm{L}$ response than that observed for Group 1 (0.079 v. $0.036 \mu \mathrm{mol} / \mathrm{l}$ per $\mathrm{mg}$, respectively). The only other previous study that reported on serum response to a formulation similar to Group 2 was conducted by Thurnham et $a l^{(25)}$ in 2008. In that study, nineteen subjects were supplemented with $10 \mathrm{mg} \mathrm{L}, 1.2 \mathrm{mg}$ of $\mathrm{Z}$ and $8 \mathrm{mg}$ of $\mathrm{MZ}$ (LuteinPlus $^{\mathrm{TM}}$ ), and a lower $\mathrm{L}$ response $(0.056 \mu \mathrm{mol} / \mathrm{l}$ per $\mathrm{mg}$ ) was reported than that reported in the present study $(0.079 \mu \mathrm{mol} / 1$ per $\mathrm{mg})$. In a different study, Thurmann et al. ${ }^{(36)}$ reported serum responses to two different dosages of almost pure L $(4 \cdot 1$ and $20.5 \mathrm{mg} / \mathrm{d})$. In that $42 \mathrm{~d}$ study, the

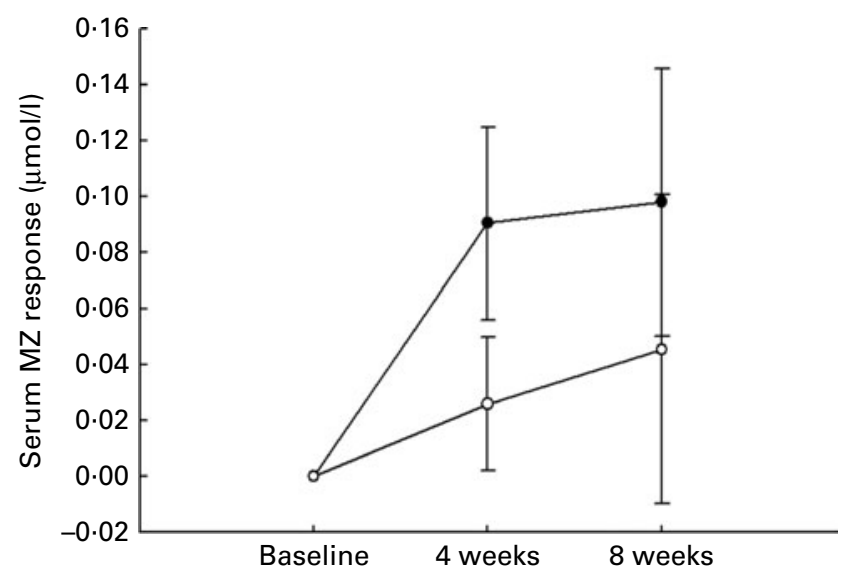

Fig. 3. Serum meso-zeaxanthin $(\mathrm{MZ})$ response ( $\mu \mathrm{mol} / \mathrm{l})$ observed for Group 3, divided by ocular status (normal subjects (-o-) v. age-related macular degeneration subjects $(\bullet-))$. 
Table 5. Serum carotenoid response per mg of supplemental carotenoid, following supplementation with the macular carotenoids

\begin{tabular}{|c|c|c|c|c|c|c|c|c|c|c|c|}
\hline Principal author & Journal & Year & $n$ & $\begin{array}{c}\text { Age } \\
\text { (years) }\end{array}$ & L & Z & $M Z$ & $\begin{array}{c}\mathrm{L} \text { response } \\
(\mu \mathrm{mol} / \mathrm{l} \\
\text { per } \mathrm{mg})\end{array}$ & $\begin{array}{c}Z \text { response } \\
(\mu \mathrm{mol} / \mathrm{l} \\
\text { per } \mathrm{mg})\end{array}$ & $\begin{array}{c}\mathrm{MZ} \text { response } \\
(\mu \mathrm{mol} / \mathrm{l} \\
\text { per } \mathrm{mg})\end{array}$ & $\begin{array}{c}\text { Duration } \\
\text { (weeks) }\end{array}$ \\
\hline \multicolumn{12}{|l|}{ Normal subjects } \\
\hline Bone et al. ${ }^{(29)}$ & $J N$ & 2003 & 21 & $19-59$ & $2 \cdot 4$ & $-{ }^{*}$ & - & 0.100 & - & - & 24 \\
\hline \multirow{4}{*}{ Bone et al. ${ }^{(42)}$} & $A B B$ & 2010 & 17 & $18-30$ & 5 & - & - & 0.035 & _- & - & 20 \\
\hline & & & 22 & $18-30$ & 10 & - & - & 0.071 & - & - & 20 \\
\hline & & & 24 & $18-30$ & 20 & - & - & 0.053 & - & - & 20 \\
\hline & & & 14 & $51-64$ & 20 & - & - & 0.071 & - & - & 20 \\
\hline Koh et al. ${ }^{(43)}$ & $E E R$ & 2004 & 6 & $58-72$ & 10 & - & - & 0.168 & - & - & 19 \\
\hline Berendschot et al. ${ }^{(44)}$ & IOVS & 2000 & 8 & $18-50$ & 10 & - & - & 0.072 & - & - & 12 \\
\hline Zhao et al. ${ }^{(45)}$ & $A J C N$ & 2006 & 8 & $50-70$ & 12 & - & - & 0.116 & - & - & 8 \\
\hline Hughes et al. ${ }^{(46)}$ & $J I D$ & 2000 & 21 & $26-56$ & 15 & _- & - & 0.092 & _- & _- & 4 \\
\hline \multirow[t]{2}{*}{ Hartmann et al. ${ }^{(37)}$} & $A J C N$ & 2004 & 10 & $28-38$ & - & 1 & - & - & 0.152 & - & 42 \\
\hline & & & 10 & $28-43$ & _- & 10 & _- & _- & 0.087 & _- & 42 \\
\hline Schalch et al. ${ }^{(39)}$ & $A B B$ & $2007 \dagger$ & 16 & $18-45$ & - & $12 \cdot 6$ & - & - & 0.064 & - & 24 \\
\hline Bone et al. ${ }^{(29)}$ & $J N$ & 2003 & 2 & $21-53$ & - & 30 & - & - & 0.014 & - & 12 \\
\hline \multirow{2}{*}{ Thurmann et al. ${ }^{(36)}$} & $A J C N$ & 2005 & 8 & $21-37$ & 4.1 & 0.58 & & 0.093 & - & _- & 42 \\
\hline & $A J C N$ & 2005 & 8 & $24-34$ & 20.5 & $2 \cdot 9$ & & 0.064 & - & - & 42 \\
\hline \multirow{2}{*}{ Schalch et al. ${ }^{(39)}$} & $A B B$ & $2007 \dagger$ & 18 & $18-45$ & $10 \cdot 7$ & 0.8 & - & 0.078 & 0.063 & - & 24 \\
\hline & & & 19 & $18-45$ & $10 \cdot 2$ & 11.9 & - & 0.037 & 0.046 & - & 24 \\
\hline Huang et al. ${ }^{(47)}$ & IOVS & 2008 & 40 & $64-86$ & 10 & 2 & - & 0.041 & 0.046 & - & 24 \\
\hline Johnson et al. ${ }^{(38)}$ & $A J C N$ & 2008 & 11 & $60-80$ & 12 & 0.5 & - & 0.022 & 0.03 & - & 16 \\
\hline Nolan et al. ${ }^{(18)}$ & $V R$ & 2011 & 61 & $18-41$ & 12 & 1 & - & 0.053 & -0.003 & - & 48 \\
\hline Johnson et al. ${ }^{(35)}$ & $A J C N$ & 2000 & 7 & $33-54$ & $19 \cdot 7$ & 1 & - & 0.018 & 0.016 & - & 15 \\
\hline Bone et al. ${ }^{(29)}$ & $J N$ & 2003 & 2 & $42-53$ & 30 & 1.5 & _- & 0.063 & 0 & - & 20 \\
\hline Connolly et al. ${ }^{(23)}$ & CER & 2010 & 5 & $18-60$ & 3.7 & 0.8 & $7 \cdot 3$ & 0.019 & -0.028 & 0.006 & 8 \\
\hline Thurnham et al. (25) & $B J N$ & 2008 & 19 & $21-46$ & $10 \cdot 8$ & 1.2 & 8 & 0.056 & 0.088 & 0.026 & 3 \\
\hline Bone et al. & $N M$ & $2007 \dagger$ & 10 & $21-58$ & 5.5 & 1.4 & 14.9 & 0.014 & $0.121 \ddagger$ & - & 17 \\
\hline \multicolumn{12}{|l|}{ AMD subjects } \\
\hline Connolly et al. (23) & CER & 2010 & 5 & $18-60$ & 3.7 & 0.8 & $7 \cdot 3$ & 0.012 & 0.035 & 0.004 & 8 \\
\hline Koh et al. ${ }^{(43)}$ & $E E R$ & 2004 & 7 & $60-81$ & 10 & - & - & 0.157 & - & - & 19 \\
\hline Khachik et al. ${ }^{(48)}$ & IOVS & 2006 & 15 & $60+$ & 10 & 0.5 & - & 0.079 & 0.076 & - & 24 \\
\hline Trieschmann et al. ${ }^{(49)}$ & $E E R$ & 2007 & 97 & $51-87$ & 12 & 1 & - & 0.036 & 0.004 & - & 36 \\
\hline \multirow[t]{3}{*}{ Present study } & & & 21 & $53-75$ & 20 & 0.86 & - & 0.036 & 0.016 & - & 8 \\
\hline & & & 20 & $53-71$ & 10 & 2 & 10 & 0.079 & 0.015 & 0.005 & 8 \\
\hline & & & 13 & $53-73$ & 3 & 2 & 17 & 0.006 & -0.002 & 0.004 & 8 \\
\hline
\end{tabular}

L, lutein; Z, zeaxanthin; MZ, meso-zeaxanthin; JN, Journal of Nutrition; ABB, Archives of Biochemistry and Biophysics; EER, Experimental Eye Research; IOVS, Investigative Ophthalmology and Visual Science; AJCN, American Journal of Clinical Nutrition; JID, Journal of Infectious Diseases; VR, Vision Research; CER, Current Eye Research; BJN, British Journal of Nutrition; NM, Nutrition and Metabolism; AMD, age-releated macular degeneration.

* Data unavailable.

†Free (unesterified) carotenoid supplement.

$\ddagger$ Includes MZ supplementation.

authors found that the rate of increase in serum $\mathrm{L}$ was greater for the low-dose L supplement when compared with the high-dose L supplement $(0.093$ and $0.064 \mu \mathrm{mol} / 1$ per $\mathrm{mg}$, respectively). However, as expected, supplementation with high-dose $\mathrm{L}$ did result in a significantly higher absolute $\mathrm{L}$ concentration in serum than seen following supplementation with low-dose L. Indeed, these findings are consistent with the results of the present study.

While a lower serum response to L in Group 3 (the high MZ group) was expected, reflecting its lower dosage (only $3 \mathrm{mg} \mathrm{L}$ ), the lack of any response was not anticipated and did not compare well with other studies ${ }^{(29,36)}$. Bone et al. ${ }^{(29)}$ reported that only $2.4 \mathrm{mg}$ of $\mathrm{L} / \mathrm{d}$ achieved a $0 \cdot 100 \mu \mathrm{mol} / \mathrm{l}$ per $\mathrm{mg}$ response in serum L. However, our data (for Group 3) are in agreement with a more recent study by Bone et al. ${ }^{(24)}$, which found that a supplement containing $5.5 \mathrm{mg} \mathrm{L}, 1.4 \mathrm{mg}$ $\mathrm{Z}$ and $14.9 \mathrm{mg} \mathrm{MZ}$ achieved only a $0.001 \mu \mathrm{mol} / \mathrm{l}$ per $\mathrm{mg}$ response in serum $\mathrm{L}$, while $0.012 \mu \mathrm{mol} / 1$ per $\mathrm{mg}$ was observed for the total $\mathrm{Z}$ fraction (the dominant carotenoids in their formulation).
Interpretation of our data for serum $\mathrm{L}$ response suggests that uptake of L may be inhibited when MZ is present in the supplement formulation in very high amounts (e.g. Group 3 where MZ was $77 \%$ ), but uptake of L may be unaffected or facilitated when the combined amounts of $M Z$ and $Z$ are present in more comparable amounts to L (i.e. as in Group 2). Whether high amounts of $Z$ in a supplement has the same effect on L uptake into serum, as seen here with MZ, has not yet been studied, but warrants attention. Thus, in the present study, our data demonstrate a greater serum response to supplemental $\mathrm{L}$ when the macular carotenoids are provided in a L:Z:MZ ratio of 10:2:10, possibly representing an interactively additive relationship that is dependent on a ratio approximating the Group 2 formulation.

\section{Serum zeaxanthin response}

$\mathrm{Z}$ was present in all three intervention groups as follows: Group 1 containing $2 \mathrm{mg} \mathrm{Z}$, and Groups 2 and 3 each containing $2 \mathrm{mg} \mathrm{Z}$ in their respective formulations. Interestingly, the 
increase in serum $Z$ is comparable between Groups 1 and 2 . Also, the $Z$ response for all groups in the present study is lower, when compared with reports by Hartman et al. ${ }^{(37)}$ and Thurnham et $a l .{ }^{(25)}(0.088 \mu \mathrm{mol} / 1$ per $\mathrm{mg}$ and $0.087 \mu \mathrm{mol} / 1$ per $\mathrm{mg}$, respectively).

Surprisingly, the Group 3 intervention did not achieve any serum $Z$ response, suggesting that very high amounts of $M Z$ (i.e. $17 \mathrm{mg}$, as in Group 3) in a supplement inhibits uptake of $\mathrm{Z}$ and is also consistent with previously published data ${ }^{(23)}$. Further, Bone et al. ${ }^{(29)}$ and Schalch et al. ${ }^{(39)}$ have each reported maximum serum $Z$ response when this carotenoid is supplemented in the absence of other carotenoids, but this does not agree with the observations of Hartmann et al. ${ }^{(37)}$ and Thurnham et al. ${ }^{(25)}$, who obtained high $\mathrm{Z}$ responses with very different supplement compositions. Nevertheless, several other studies report a reduced $\mathrm{Z}$ response in the presence of high amounts of $\mathrm{L}$, as observed in the present study in Group 1 (see Table 5 for comparison) ${ }^{(29,35,38,39)}$.

Interpretation of our data for serum $Z$ response suggests that uptake of $Z$ is inhibited when supplemented with very high quantities of MZ (Group 3). It is possible that the inhibitions seen in Group 3 are due to the structural and chemical similarities between $\mathrm{Z}$ and $\mathrm{MZ}$, which might cause them to compete for absorption. Differences between the present study and other studies with respect to absorption of $\mathrm{Z}$ may also be explained by differences in the supplement components (e.g. type of carotenoid suspension) and/or differences in dietary habits of the subjects.

\section{Serum meso-zeaxanthin response}

MZ was present in two of the three interventions as follows: Group 2 containing $10 \mathrm{mg}$ of $\mathrm{MZ}$ and Group 3 containing $17 \mathrm{mg}$ of MZ. Of interest, both groups that were supplemented with $M Z$ demonstrated a serum response to this carotenoid. This finding is important given that MZ has yet to be found in a typical diet in large amounts, and therefore uptake into serum of this carotenoid warranted investigation. Indeed, our observation in this regard is consistent with a previous report by our group ${ }^{(23)}$. Further, serum MZ increases for both Groups 2 and 3 were comparable, but four to five times lower than that previously reported by Thurnham et $a{ }^{(25)}$. It is important to point out that, in terms of absolute values, circulating concentrations of $M Z$ were lower than those of either $\mathrm{L}$ or $\mathrm{Z}$, in spite of the high doses given. However, we propose that, as MZ is not known to be present in a typical diet, newly absorbed MZ could be directed to potential storage tissues and, as a result, concentrations in the blood may take many weeks to reach saturation, thereby explaining the low circulating concentrations of this carotenoid when compared with either L or Z following supplementation. Previous studies have reported that $\mathrm{MZ}$ was less readily absorbed than other $\mathrm{Z}$ isomers ${ }^{(40)}$, but nevertheless the amount present in blood is likely to be sufficient to supplement the macula, where the average amount of MZ measured within $24 \mathrm{~h}$ of death was $7.7 \mathrm{ng}^{(41)}$. Also, it is possible that we simply have, and need, less MZ in serum compared with the other macular carotenoids, as its presence in tissue (with the exception of the macula) is unknown. In other words, it is possible that, in human subjects, MZ is found only at the macula, and study is warranted to investigate its presence, or absence, in other tissues (including the brain).

An interesting finding was the unexpected observation of a peak with the spectrophotometric characteristics of MZ in the serum of Group 1 subjects at 4 and 8 weeks. Subjects in Group 1 received no MZ (at least according to the box label claim). Given that this was an unexpected finding, we reanalysed random serum samples from Group 1 in order to confirm or refute our observation, and confirmed that MZ was, indeed, present in the serum of these subjects. We then tested the Group 1 intervention formulation (Ultra Lutein ${ }^{\circledR}$ from Nature's Plus ${ }^{\circledR}$ : L provided by FloraGLO ${ }^{\circledR}$ which is a registered trademark of Kemin Health, L.C.) and determined that this formulation did, in fact, contain MZ ( $0.3 \mathrm{mg}$ per capsule), which we believe explains the observation that Group 1 subjects exhibited a trace peak with the spectrophotometric characteristics of $\mathrm{MZ}$ in serum at 4 and 8 weeks. We then went on to test the composition of the other interventions used in the present study and found that they were concordant with their respective label claims (see Table 3). These findings have implications on the ongoing research surrounding carotenoid supplementation. Indeed, any discrepancy between actual and alleged concentrations of the respective macular carotenoids in commercially available preparations is particularly important when such formulations are used for research. Consequently, the concentration of all three macular carotenoids in a wide array of commercially available formulations and foods, with particular attention directed towards MZ, will be the subject of further study by our laboratory.

\section{Conclusion}

The present study has yielded important and novel findings, such as the presence of $\mathrm{MZ}$ in the serum of normal and AMD subjects following supplementation with high doses of L, and the significantly greater serum MZ response amongst subjects with AMD $v$. normal subjects following supplementation in the high MZ group. A limitation of the present study rests on the absence of a placebo arm, and further research should therefore include a placebo control group. Moreover, a head-to-head trial of supplemental MZ $v$. supplemental Z (in comparable amounts) would also enhance our understanding of serum response to supplementation with the macular carotenoids.

We conclude that all three macular carotenoid interventions resulted in significant serum carotenoid response, albeit to varying extents. Group 2, an intervention containing $2 \mathrm{mg} \mathrm{Z}$, $10 \mathrm{mg} \mathrm{L}$ and $10 \mathrm{mg} \mathrm{MZ}$ achieved the greatest composite serum response for these carotenoids (i.e. total macular carotenoid response). In other words, it appears that a formulation containing all three macular carotenoids was more efficacious in terms of achieving a higher concentration of circulating levels of total macular carotenoids, thereby potentially optimising the bioavailability of these compounds for capture by the target tissue (retina). 


\section{Acknowledgements}

The authors acknowledge the support given by the Howard Foundation, Cambridge, UK. J. M. N. is a Fulbright Scholar and is funded by the European Research Council (ERC). K. A. M. carried out the experimental procedures, the data interpretation and statistical analysis, and drafted the manuscript. D. I. T. helped with data interpretation and statistical analysis, and helped to draft the manuscript. S. B. helped to the draft the manuscript. A. N. H. helped with the design of the trial and to draft the manuscript. E. C. carried out the recruitment of subjects, managed the clinical visitations and collected the serum samples. W. C. supported the experimental procedures. J. M. N. designed and supervised the study, helped with data interpretation and statistical analysis and helped to draft the manuscript. All authors have read and approved the manuscript. J. M. N. and S. B. do consultancy work for nutraceutical companies, in a personal capacity, and as directors of Nutrasight Consultancy Limited. D. I. T. is a consultant to the Howard Foundation and receives consulting fees for the same. All other authors report no potential conflicts of interest.

\section{References}

1. Britton G (1995) Structure and properties of carotenoids in relation to function. FASEB J 9, 1551-1558.

2. Young AJ \& Frank HA (1996) Energy transfer reactions involving carotenoids: quenching of chlorophyll fluorescence. J Photochem Photobiol B 36, 3-15.

3. Harrison EH (2012) Mechanisms involved in the intestinal absorption of dietary vitamin A and provitamin A carotenoids. Biochim Biophys Acta 1821, 70-77.

4. Bone RA, Landrum JT, Hime GW, et al. (1993) Stereochemistry of the human macular carotenoids. Inves Ophthalmol Visual Sci 34, 2033-2040.

5. Hirsch J \& Curcio CA (1989) The spatial resolution capacity of human foveal retina. Vision Res 29, 1095-1101.

6. Khachik F, Spangler CJ, Smith JC, et al. (1997) Identification, quantification, and relative concentrations of carotenoids and their metabolites in human milk and serum. Anal Chem 69, 1873-1881.

7. Bone RA, Landrum JT \& Tarsis SL (1985) Preliminary identification of the human macular pigment. Vision Res 25, 1531-1535.

8. Beatty S, Koh HH, Henson D, et al. (2000) The role of oxidative stress in the pathogenesis of age-related macular degeneration. Surv Ophthalmol 45, 115-134.

9. Snodderly DM \& Hammond BR (1999) Nutritional and Environmental Influences on Vision. Boca Raton, FL: CRC Press.

10. Trevithick-Sutton CC, Foote CS, Collins M, et al. (2006) The retinal carotenoids zeaxanthin and lutein scavenge superoxide and hydroxyl radicals: a chemiluminescence and ESR study. Mol Vis 12, 1127-1135.

11. Pintea A, Socaciu C, Rugina DO, et al. (2011) Xanthophylls protect against induced oxidation in cultured human retinal pigment epithelial cells. J Food Compos Anal 26, 830-836.

12. Junghans A, Sies H \& Stahl W (2001) Macular pigments lutein and zeaxanthin as blue light filters studied in liposomes. Arch Biochem Biophys 391, 160-164.
13. Bone RA, Landrum JT, Friedes LM, et al. (1997) Distribution of lutein and zeaxanthin stereoisomers in the human retina. Exp Eye Res 64, 211-218.

14. Li B, Ahmed F \& Bernstein PS (2010) Studies on the singlet oxygen scavenging mechanism of human macular pigment. Arch Biochem Biophys 504, 56-60.

15. Bressler NM (2004) Age-related macular degeneration is the leading cause of blindness. JAMA 291, 1900-1901.

16. Loane E, Kelliher C, Beatty S, et al. (2008) The rationale and evidence base for a protective role of macular pigment in age-related maculopathy. Br J Ophthalmol 92, 1163-1168.

17. Loughman J, Davison PA, Nolan JM, et al. (2010) Macular pigment and its contribution to visual performance and experience. J Optomet 3, 74-90.

18. Nolan JM, Loughman J, Akkali MC, et al. (2011) The impact of macular pigment augmentation on visual performance in normal subjects: COMPASS. Vision Res 51, 459-469.

19. Stringham JM, Garcia PV, Smith PA, et al. (2011) Macular pigment and visual performance in glare: benefits for photostress recovery, disability glare, and visual discomfort. Invest Ophthalmol Vis Sci 52, 7406-7415.

20. Perry A, Rasmussen H \& Johnson EJ (2009) Xanthophyll (lutein, zeaxanthin) content in fruits, vegetables and corn and egg products. J Food Compos Anal 22, 9-15.

21. Maoka T, Arai A, Shimizu M, et al. (1986) The first isolation of enantiomeric and meso-zeaxanthin in nature. Comp Biochem Physiol B 83, 121-124.

22. Johnson EJ, Neuringer M, Russell RM, et al. (2005) Nutritional manipulation of primate retinas, III: effects of lutein or zeaxanthin supplementation on adipose tissue and retina of xanthophyll-free monkeys. Invest Ophthalmol Vis Sci 46, 692-702.

23. Connolly EE, Beatty S, Thurnham DI, et al. (2010) Augmentation of macular pigment following supplementation with all three macular carotenoids: an exploratory study. Curr Eye Res 35, 335-351.

24. Bone RA, Landrum JT, Cao Y, et al. (2007) Macular pigment response to a supplement containing meso-zeaxanthin, lutein and zeaxanthin. Nutr Metab (Lond) 4, 12.

25. Thurnham DI, Tremel A \& Howard AN (2008) A supplementation study in human subjects with a combination of mesozeaxanthin, $\left(3 R, 3^{\prime} R\right)$-zeaxanthin and $\left(3 R, 3^{\prime} R, 6^{\prime} R\right)$-lutein. $B r J$ Nutr 100, 1307-1314.

26. Connolly EE, Beatty S, Loughman J, et al. (2011) Supplementation with all three macular carotenoids: response, stability, and safety. Invest Ophthalmol Vis Sci 52, 9207-9217.

27. Neelam K, Muldrew A, Hogg R, et al. (2009) Grading of agerelated maculopathy: slit-lamp biomicroscopy versus an accredited grading center. Retina 29, 192-198.

28. Loughman J, Nolan J, Stack J, et al. (2011) Online AMD research study for optometrists: current practice in the Republic of Ireland and UK. Optomet Pract 12, 135-144.

29. Bone RA, Landrum JT, Guerra LH, et al. (2003) Lutein and zeaxanthin dietary supplements raise macular pigment density and serum concentrations of these carotenoids in humans. J Nutr 133, 992-998.

30. Kirby ML, Beatty S, Loane E, et al. (2010) A central dip in the macular pigment spatial profile is associated with age and smoking. Invest Ophthalmol Vis Sci 51, 6722-6728.

31. Bone RA, Landrum JT, Mayne ST, et al. (2001) Macular pigment in donor eyes with and without AMD: a case-control study. Invest Ophthalmol Vis Sci 42, 235-240.

32. Nolan JM, Stack J, O'Donovan, et al. (2007) Risk factors for age-related aculopathy are associated with a relative lack of macular pigment. Exp Eye Res 84, 61-74. 
33. Wang W, Connor SL, Johnson EJ, et al. (2007) Effect of dietary lutein and zeaxanthin on plasma carotenoids and their transport in lipoproteins in age-related macular degeneration. Am J Clin Nutr 85, 762-769.

34. Hammond BR, Wooten BR \& Snodderly DM (1999) A practical method for measuring macular pigment optical density in diverse populations. Invest Ophthalmol Vis Sci 40, 2481-2489.

35. Johnson EJ, Hammond BR, Yeum KJ, et al. (2000) Relation among serum and tissue concentrations of lutein and zeaxanthin and macular pigment density. Am J Clin Nutr $\mathbf{7 1}$, 1555-1562.

36. Thurmann PA, Schalch W, Aebischer JC, et al. (2005) Plasma kinetics of lutein, zeaxanthin, and 3-dehydro-lutein after multiple oral doses of a lutein supplement. Am J Clin Nutr 82, 88-97.

37. Hartmann D, Thurmann PA, Spitzer V, et al. (2004) Plasma kinetics of zeaxanthin and $3^{\prime}$-dehydro-lutein after multiple oral doses of synthetic zeaxanthin. Am J Clin Nutr 79, 410-417.

38. Johnson EJ, Chung HY, Caldarella SM, et al. (2008) The influence of supplemental lutein and docosahexaenoic acid on serum, lipoproteins, and macular pigmentation. Am J Clin Nutr 87, 1521-1529.

39. Schalch W, Cohn W, Barker FM, et al. (2007) Xanthophyll accumulation in the human retina during supplementation with lutein or zeaxanthin - the LUXEA (LUtein Xanthophyll Eye Accumulation) study. Arch Biochem Biophys 458, $128-135$.

40. Schiedt K, Glintz E, Vecchi M, et al. (1985) Absorption, retention and metabolic transformation of carotenoids in rainbow trout, salmon and chicken. Pure Appl Chem 57, 685-692

41. Khachik F, de Moura FF, Zhao DY, et al. (2002) Transformations of selected carotenoids in plasma, liver, and ocular tis- sues of humans and in nonprimate animal models. Invest Ophthalmol Vis Sci 43, 3383-3392.

42. Bone RA \& Landrum JT (2010) Dose-dependent response of serum lutein and macular pigment optical density to supplementation with lutein esters. Arch Biochem Biophys 504, 50-55.

43. Koh HH, Murray IJ, Nolan D, et al. (2004) Plasma and macular responses to lutein supplement in subjects with and without age-related maculopathy: a pilot study. Exp Eye Res 79, 21-27.

44. Berendschot TTJM, Goldbohm RA, Klöpping WAA, et al. (2000) Influence of lutein supplementation on macular pigment, assessed with two objective tecniques. Invest Ophthalmol Vis Sci 41, 3322-3326.

45. Zhao X, Aldini G, Johnson EJ, et al. (2006) Modification of lymphocyte DNA damage by carotenoid supplementation in postmenopausal women. Am J Clin Nutr 83, 163-169.

46. Hughes DA, Wright AJ, Finglas PM, et al. (2000) Effects of lycopene and lutein supplementation on the expression of functionally associated surface molecules on blood monocytes from healthy male nonsmokers. J Infect Dis 182, Suppl. 1, S11-S15.

47. Huang LL, Coleman HR, Kim J, et al. (2008) Oral supplementation of lutein/Zeaxanthin and omega-3 long chain polyunsaturated fatty acids in persons aged 60 years or older, with or without AMD. Invest Ophthalmol Vis Sci 49, 3864-3869.

48. Khachik F, de Moura FF, Chew EY, et al. (2006) The effect of lutein and zeaxanthin supplementation on metabolities of these carotenoids in the serum of persons aged 60 or older. Invest Ophthalmol Vis Sci 47, 5234-5242.

49. Trieschmann M, Beatty S, Nolan M, et al. (2007) Changes in macular pigment optical density and serum concentrations of its constitutent carotenoids following supplemental lutein and zeaxanthin: the LUNA study. Exp Eye Res 84, $718-728$. 